\title{
8. POSVET
}

\section{DNEVI KADROVSKIH DELAVCEV 2004}

\section{9. in 20. aprila 2004 v Portorožu}

A djetja GV Izobraževanje in revije HRM potekalo že 8 . tradicionalno srečanje kadrovskih menedžerjev Dnevi kadrovskih delavcev 2004. Letošnji posvet je potekal v luči vstopa Slovenije v EU s poudarkom na novostih na področju kadrovskega menedžmenta pred vstopom v EU.

Moderator konference mag. Bor Rozman, izvršni direktor za kadrovsko-pravno področje $v$ Merkurju, je srečanje pričel $z$ uvodno mislijo Petra Druckerja, priznanega avtorja: "Vse organizacije, podjetja in ustanove danes rutinsko zatrjujejo, da so ljudje njihovo največje bogastvo. Le malo jih $v$ resnici misli tako in še manj jih deluje $v$ tej smeri!" Gre za ustaljeno frazo, ki jo radi uporabijo menedžerji, ne bi pa smela biti tudi miselnost tistih, ki dejansko delajo z ljudmi, torej kadrovskih menedžerjev. Dobra iztočnica torej za letno srečevanje in izobraževanje.

Posvet je bil tudi letos bogat $\mathrm{z}$ različnimi vsebinami, slišali pa smo kar 21 domačih in tujih predavateljev.

Najaktualnejše je bilo gotovo zasedanje EU, v katerem je $d r$. Zvone Vodovnik s Fakultete za upravo $v$ Ljubljani predstavil socialni dialog $\checkmark$ EU in kolektivne pogodbe, izkušnje in trende na področju udeležbe na dobičku zaposlenih v EU pa sta predstavila tuji gost posveta, Christian Welz iz Evropske fondacije za izboljšanje življenjskih in delovnih razmer v Dublinu in dr. Aleksandra Kanjuo Mrčela s Fakultete za družbene vede $v$ Ljubljani. Evropska fondacija je na področju udeležbe na dobičku zaposlenih $v$ EU pripravila raziskavo, ki je pokazala na rast udeležbe na dobičku zaposlenih, poleg tega pa tudi, da zakonodaja in davčne olajšave moěno vplivajo na uveljavitev programov udeležbe pri dobičku zaposlenih.

O prihodnosti zaposlovanja tako $\vee$ EU kot tudi v Sloveniji, o vojni za talente na vse konkurenčnejšem trgu in o e-kadrovanju je govoril Tomi Prosnik iz Oxylusa.

Kadrovska funkcija ima pri vseh navedenih področjih zelo pomembno vlogo; potrebno je prilagajanje slovenskim razmeram na področju socialnega partnerstva, udeležbe pri dobičku, davčne politike, dvigovanja kompetentnosti in znanja, ustvarjanja pogojev za nenehno spreminjanje in učenje. EU in globalizacija zahtevata namreč hitrost, spreminjanje in rast. Naloga kadrovskih strokovnjakov je tudi vnašati več poguma in samozavesti v organizacije ob vstopu v EU.

$Z$ vstopom naše države v EU je povezano tudi sprejetje novega Zakona o dohodnini, katerega novosti je predstavil Klemen Šešok iz 
podjetja Taxgroup. Našo zakonodajo bo potrebno prílagoditi sproščanju tokov na področju pretoka ljudi, storitev in kapitala, sistem dohodnine pa prilagoditi mednarodno primerljivim standardom.

Zanimiv je bil tudi odprti forum z aktualno temo "Nova kolektivna pogodba kot orodje kadrovskega menedžmenta". Sodelujoči v razpravi so izpostavili, da mora kadrovska stroka zavzeti stališče, ali sploh potrebujemo kolektivno pogodbo ter kakšna je uporaba podjetniških kolektivnih pogodb po uveljavitvi novega Zakona o delovnih razmerjih. Predlog Zakona o kolektivnih pogodbah je $\mathrm{v}$ obravnavi že več kot 10 let, tako da gre za eno izmed področij delovnega prava, ki odpira marsikatera vprašanja.

$\mathrm{O}$ vplivu gospodarskih in političnih trendov $\mathrm{v}$ EU ter vlogi menedžementa pri razvoju kadrovske funkcije sta spregovorila Peter Kraljič, priznani svetovalec in dolgoletni direktor svetovalne hiše McKinsey \& Co., ter Milan Bavec, direktor podjetja Iskra Mehanizmi, ki je kot prvo podjetje $v$ Sloveniji pridobilo standard kakovosti na področju ravnanja z zaposlenimi "Vlagatelji v Jjudi".

Dr. Miroslav Glas z Ekonomske fakultete v Ljubljani je predstavil aktualno temo, o kateri je vse premalo govora: ali delujemo v skladu s pravili poslovne etike ali smo pošteni. Poudaril je, da so vodje zgled zaposlenim, od katerih je odvisna tudi etičnost poslovanja podjetja. Etičnost poslovanja je prav tako odvisna od vrednot in kulture $v$ podjetju. Organizacijska kultura je temelj konkurenčne prednosti in gibalo napredka podjetja, kot je predstavil $d r$. Milan Pagon s Fakultete za policijsko-varnostne vede in Fakultete za organizacijske vede v Mariboru.

$\mathrm{Z}$ interno klimo in vrednotami zaposlenih se ukvarjajo tudi y Zavarovalnici Triglav, d. d., OE Murska Sobota. Viktor Vild je v sodelovanju s svetovalcem Dušanom Vrbanom iz projektne skupine Kainoto predstavil razi- skavo o zadovoljstvu in vrednotah zaposlenih, ki so jo izvedli $v$ zavarovalnici. Le skladnost osebnih vrednot zaposlenih z vrednotami podjetja namreč daje dobre rezultate in pripadnost podjetju, na zadovoljstvo in motiviranost zaposlenih pa imajo velik vpliv tudi vodje. Predavatelja sta tudi izpostavila, da morajo kadrovski strokovnjaki med drugim skrbeti tudi za t, i, kadrovski marketing in povezovanje med kadrovsko funkcijo in marketingom.

Letos je bilo prvič govora tudi o Psihosocialnih elementih načrtovanja kariere, na katere kadrovski menedžerji $v$ globałni konkurenčni tekmi pogosto pozabijo. Tri vzporedne življenjske cikle in njihove glavne značilnosti, ki bi jih moral poznati in upoštevati vsak kadrovski strokovnjak, je na posvetu predstavila mag. Daniela Brečko, direktorica podjetja GV Izobraževanje.

In kateri je najboljši delodajalec v Sloveniji po raziskavi "Najboljši delodajalec 20032004"? Najbolje se je odrezalo podjetje Danfoss Trata, ki se je uvrstilo na 33. mesto v Evropi. Na to mesto jih gotovo uvrščajo yodenje s cilji, procesna organiziranost, dobra organizacijska kultura $v$ podjetju, stalne izboljšave in skupinsko delo. Vse to vpliva na vključenost zaposlenih in prevzemanje odgovornosti.

Na posvetu so bili predstavljeni tudi lanskoletni projekti razpisa za najboljši HRM projekt 2003. Nagrajeni projekt iz Bolnišnice Golnik KOPA "Krožki kakovosti kot način vlaganja v ljudi" je nastal z namero izboljšanja kakovosti $v$ zdravstveni negi in uporabo metode skupnega načrtovanja.

Ključna misel letošnjih 8 . dnevov je gotovo misel, da je kadrovska funkcija nadvse pomembna pri vstopu SIovenije v EU, saj skrbi za ljudi, torej gonilno silo organizacij, in da je $\mathrm{v}$ organizacijah dejansko strateški partner in ne le obrobna, izolirana funkcija. Seveda se pri tem ne moremo izogniti tudi 
vplivu in prispevku vodij in njihovega zavedanja, da je strateško partnerstvo s kadrovsko funkcijo nadvse pomembno. Še bolj v tem času, ko vstopamo na enoten in globalen trg. Upamo torej, da bodo slovenski kadrovski menedžerji vstopili $v$ EU polni optimizma in z zaupanjem $v$ njihovo poslanstvo!

Prispevki iz posveta so zbrani v 4. aprilski številki revije HRM, strokovne revije za ravnanje z ljudmi pri delu. Več o reviji na www.gvizobrazevanje.si.

Monika Zalokar 